\title{
Concrescence of an Erupted Maxillary Second Molar with an Impacted Third Molar: A Case Report
}

\author{
Nour Shazli ${ }^{1}$, Mazen Almasri, ${ }^{2 * *}$ \\ ${ }^{1}$ Faculty of Dentistry, King Abulaziz University, Jeddah, Saudi Arabia \\ ${ }^{2}$ Oral Maxillofacial Surgery Department, Faculty of Dentistry, King Abulaziz University, Jeddah, Saudi Arabia \\ *Corresponding author: mazen_ajm@yahoo.com
}

\begin{abstract}
The aim is to report a rare anomaly of a concrescent maxillary second molar with the adjacent impacted third molar discovered upon routine dental extraction and discussing the situation throughout the procedure, the possible complications, the considerations, and reviewing similar cases reported in the literature.
\end{abstract}

Keywords: concrescence, fusion, second molar, third molar, wisdom teeth

Cite This Article: Nour Shazli, and Mazen Almasri, "Concrescence of an Erupted Maxillary Second Molar with an Impacted Third Molar: A Case Report.” Oral Surgery, Oral Medicine, Oral Radiology, vol. 5, no. 1 (2017): 1-3. doi: 10.12691/oral-5-1-1.

\section{Introduction}

Concrescence is a dental anomaly where two fully formed teeth are fused with cementum. The incidence of concrescent teeth is highest in the posterior maxilla. The etiology of this phenomenon needs yet to be further investigated [1]. However, many studies show that chronic irritation such as that caused by long-standing carious lesions, may cause the deposition of cementum between the roots [2]. Additional factors that may cause concrescence include, secondary trauma and rapid orthodontic tooth movement.

It is difficult for clinicians to ascertain whether the roots are fused, overlapped, or merely in close proximity to one another based on a radiograph. Therefore, juxtaposed teeth pose a challenge in diagnosis and treatment planning [1].

An advanced search was conducted using the "Google Scholar" and "PubMed" electronic databases. Keywords such as "concrescence”, "fusion”, "maxillary second molars”, "maxillary third molars" and "wisdom teeth" were used on "Google Scholar". From the 394 results, only 7 were eligible and presented similar clinical finding to this case. "Concrescence" was used on "PubMed" and 68 search results arose. Only 8 were selected based on "English" being the article language, year of publication (2000-2017), and similarity of clinical finding to this case. Due to the rarity of the anomaly, this case is important to document.

To our knowledge, this is the first case published with similar anomaly in Saudi Arabia and the Middle East that is showing a maxillary second molar fused with the neighboring impacted third molar.

\section{Case Report}

A sixty-year-old female patient presented at the dental clinic (King Abdul-Aziz University Dental Hospital) complaining from a loose maxillary complete denture that she wishes to replace. Upon clinical examination, the maxillary arch exhibited a lone-standing left maxillary second molar, upon which the denture was clasped. It displayed active cervical caries palatally and distally, and an occlusal amalgam restoration. A horizontally impacted maxillary third molar in close proximity to the second molar was evident on a Panoramic radiograph (Figure 1). A clinical decision involving the extraction of the second molar and placement of a conventional complete denture was established.

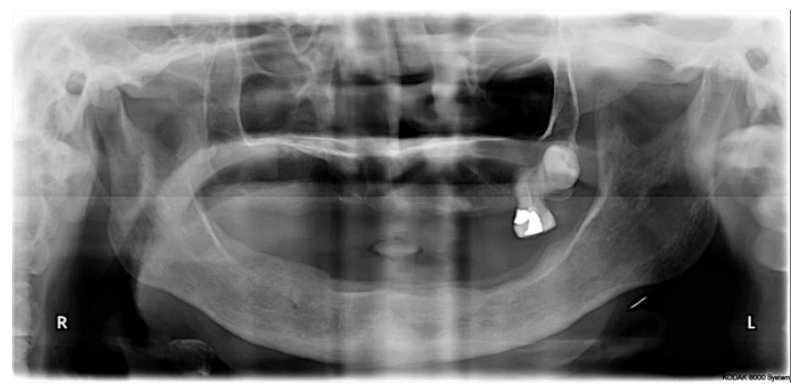

Figure 1. Presurgical panoramic radiograph showing a horizontally impacted left maxillary third molar in close proximity to second molar

An informed consent was signed prior to the extraction. The patient was anesthetized with (Lidocaine 2\% and Epinephrine 1:100k), and following complete anesthesia in this region, extraction was attempted using forceps with slow luxation and bimanual palpation of the alveolar ridge. Throughout the procedure, a moderate amount of resistance was encountered, and when the left maxillary second molar was extracted, the third molar was removed with it.

Subsequent to the extraction, it was apparent that the maxillary third molar root was fused to the second molar in the furcation area (Figure 2). The extraction socket was inspected carefully. The buccal plate of bone revealed a mild crack. The maxillary sinus was inspected to 
determine sinus communication; however, no communication was noted. Irrigation using Normal Saline and pressure packs (sterile gauze) were utilized to achieve hemostasis. Furthermore, two packets of gelfoam (Surgicel ${ }^{\circledR}$ ) were placed within the socket and held in place using a figure-of-eight suture. The patient was finally given post-operative instructions and analgesics. A radiograph was taken of the extracted teeth which suggested concrescence of these teeth (Figure 3).

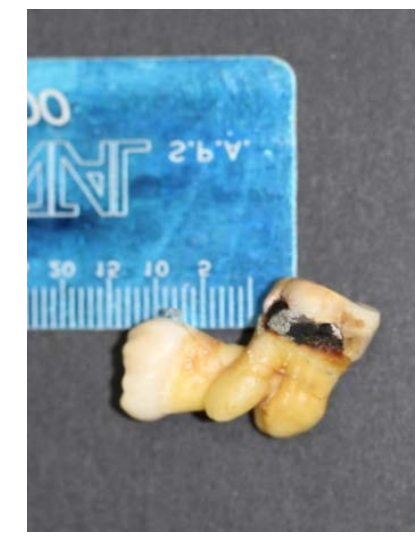

Figure 2. Concrescent left maxillary second and third molar postextraction

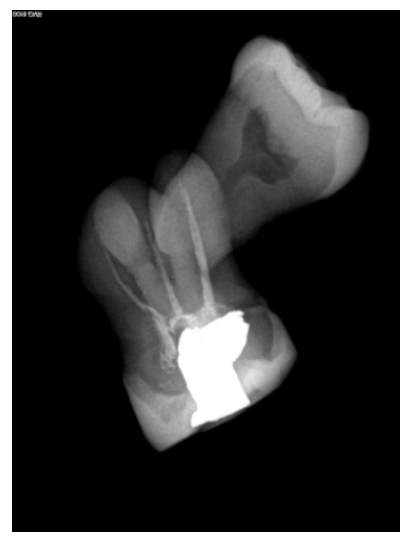

Figure 3. Specimen radiograph showing concrescent second and third molars

\section{Discussion}

Concrescence is an uncommon clinical phenomenon that is most likely found in the posterior maxilla. It is difficult to detect radiographically since the roots are fused only by cementum [10]. Thus, juxtaposed teeth usually pose a challenge in diagnoses and treatment planning. Clinically, concrescence may be impossible to detect due to the lack of enamel involvement [13]. Radiographically, concrescent teeth may be misdiagnosed as superimposed teeth. The preoperative panoramic radiograph obtained in this case raised potential concern of a possible concrescence and hence difficult extraction. A diagnosis of concrescent maxillary left second and third molars was confirmed post-extraction. Several studies emphasize the necessity to use Cone-Beam Computed Tomography (CBCT) in the diagnosis of concrescent teeth to prevent considerable complications during treatment, however it is yet not justifiable as a routine pre-extraction practice [3,5]. The use of Cone-Beam Computed Tomography eliminates limitations associated with 2D imaging, such as distortion and superimposition. Hence, it is a valuable resource in evaluating and accurately diagnosing confluent teeth [5].

Concrescence is the deposition of cementum either during root formation "true concrescence" or after root development is complete "acquired concrescence" [2]. If the anomaly was associated with the former, it is categorized as developmental and is most probably due to the close proximity of the developing roots [4]. On the other hand, if it occurs after radicular formation, it is categorized as post-inflammatory.

The literature shows a preponderance of this rare phenomenon occurring in the posterior maxilla (Appendix A). From the 13 summoned cases, only 2 were evident in the mandible. Both were cases of concrescence observed between a mandibular third molar and a supernumerary fourth molar. Nonetheless, this phenomenon is more frequently detected in maxillary molars [5,12]. Concrescence was manifested mainly in maxillary second molars in conjunction with impacted third molars. In addition, its prevalence was not affected by age, race or gender [10].

Several approaches can be considered with regards to treatment of concrescence. The treatment of choice, however, is determined by the patient's needs. Multiple studies revealed that clinicians mostly resorted to extraction. This may be due to the inadvertent diagnosis of concrescent teeth both radiographically, and during tooth extraction [6,9]. However, Foran et. al describes a unique case that was treated by non-surgical root canal treatment (NSRCT) [7].

Potential complications may arise during treatment of concrescent teeth, such as extraction of an adjacent tooth, fracture of the maxillary tuberosity, or maxillary sinus communication [11]. Therefore, it is of utmost importance for clinicians to consider concrescence when planning extractions, especially when the roots of adjacent teeth are not distinguishable radiographically.

\section{Conclusion}

Clinicians should be aware of this infrequent anomaly to avoid unnecessary complications intra-operatively such as maxillary sinus communication \& fracture of the tuberosity. Multiple radiographs should be taken prior to initiating treatment to modify the treatment plan if needed.

\section{References}

[1] Mohan, B. Hypercementosis and concrescence of maxillary second molar with third molar: a case report and review of literature. Oral Health Dent Manag. 2014; 13(2): 558-562.

[2] Mader CL. Concrescence of teeth: a potential treatment hazard. General dentistry. 1984; 32(1): 52.

[3] Ferreira-Junior O, De Ávila LD, da Silva Sampieri MB, DiasRibeiro E, Chen WL, Fan S. Impacted lower third molar fused with a supernumerary tooth-diagnosis and treatment planning using cone-beam computed tomography. International journal of oral science. 2009 Dec; 1(4): 224.

[4] Bellapu V, Nagarakanti S. Concrescence of erupted second molar and impacted third molar: A rare case report. Internet J Dent Sci. 2009; 8: 1-4. 
[5] Syed AZ, Alluri LC, Mallela D, Frazee T. Concrescence: ConeBeam Computed Tomography Imaging Perspective. Case Reports in Dentistry. 2016 Oct 9; 2016.

[6] Palermo D, Davies-House A. Unusual finding of concrescence. BMJ case reports. 2016 Mar 23; 2016: bcr2016214597.

[7] Foran D, Komabayashi T, Lin LM. Concrescence of permanent maxillary second and third molars: case report of non-surgical root canal treatment. Journal of oral science. 2012; 54(1): 133-6.

[8] Strecha J, Jurkovic R, Siebert T. Fusion of the 2nd maxillary molar with the impacted 3rd molar. Bratisl Lek Listy. 2012 Jan 1; 113(9): 569-71.

[9] Khanna S, Sandhu SV, Bansal H, Khanna V. Concrescence-A report of two cases. International Journal of Dental Clinics. 2011 Mar 31;3(1).
[10] Gernhofer KJ. Concrescence of a maxillary second and third molar. Journal of the California Dental Association. 2009 Jul; 37(7): 479-81

[11] Badjate SJ, Cariappa KM. Concrescence: report of rare complication. The New York state dental journal. 2008 Jan; 74(1): 56.

[12] Gunduz K, Sumer M, Sumer AP, Gunhan O. Concrescence of a mandibular third molar and a supernumerary fourth molar: Report of a rare case. British dental journal. 2006 Feb 11; 200(3): 141-2.

[13] Romito LM. Concrescence: Report of a rare case. Oral Surgery, Oral Medicine, Oral Pathology, Oral Radiology, and Endodontology. 2004 Mar 31; 97(3): 325-7.

\section{Appendix A}

\begin{tabular}{|c|c|c|c|c|c|c|}
\hline Author & Publication & Gender & Age & $\begin{array}{l}\text { Treatment } \\
\text { proposed }\end{array}$ & $\begin{array}{l}\text { Reasons for seeking } \\
\text { care }\end{array}$ & Side \\
\hline $\begin{array}{l}\text { Ali Zakir Syed, Leela } \\
\text { Subhashini, Choudary } \\
\text { Alluri, Dhiraj Mallela, } \\
\text { and Tro Frazee [5] }\end{array}$ & 2016, USA & M & 18-years old & $\begin{array}{l}\text { Referral for } \\
\text { appropriate } \\
\text { treatment }\end{array}$ & $\begin{array}{l}\text { Evaluation of } \\
\text { erupting third molar }\end{array}$ & $\begin{array}{l}\text { Left Mandiblular erupting third } \\
\text { molar with an impacted } \\
\text { paramolar, supernumerary fourth } \\
\text { molar }\end{array}$ \\
\hline Shazli N, Almasri M. & $\begin{array}{l}\text { 2016, Saudi } \\
\text { Arabia }\end{array}$ & F & 60-years old & Extraction & $\begin{array}{l}\text { Fabrication of } \\
\text { a Complete Denture }\end{array}$ & $\begin{array}{l}\text { Left erupted Maxillary second } \\
\text { molar with an impacted third } \\
\text { molar }\end{array}$ \\
\hline $\begin{array}{l}\text { Palermo D, Davies- } \\
\text { House A [6] }\end{array}$ & 2016, UK & F & 83-years old & Extraction & Pain & $\begin{array}{l}\text { Left erupted Maxillary first } \\
\text { molar with an erupted maxillary } \\
\text { second molar }\end{array}$ \\
\hline Bhavya, Mohan [1] & 2014, UK & F & 30-years old & Extraction & Pain & $\begin{array}{l}\text { Right erupted Maxillary second } \\
\text { molar with an erupted, slightly } \\
\text { infra-occluded third molar }\end{array}$ \\
\hline $\begin{array}{l}\text { Denise Foran, Takashi } \\
\text { Komabay-ashi, and, } \\
\text { Louis M. Lin [7] }\end{array}$ & 2012, USA & F & 35-years old & $\begin{array}{l}\text { NSRCT (Non- } \\
\text { surgical Root } \\
\text { Canal } \\
\text { Treatment) }\end{array}$ & Pain & $\begin{array}{l}\text { Right erupted Maxillary second } \\
\text { molar with an erupted third } \\
\text { molar }\end{array}$ \\
\hline $\begin{array}{l}\text { Strecha J, } \\
\text { Jurkovic R, } \\
\text { Siebert T [8] }\end{array}$ & $\begin{array}{l}\text { 2012, } \\
\text { Slovakia }\end{array}$ & M & 53-years old & Extraction & $\begin{array}{l}\text { Pain \& request for } \\
\text { extraction of an } \\
\text { upper impacted third } \\
\text { molar }\end{array}$ & $\begin{array}{l}\text { Left erupted Maxillary second } \\
\text { molar with an impacted third } \\
\text { molar }\end{array}$ \\
\hline $\begin{array}{l}\text { Sagar Khanna, } \\
\text { Simarpreet Virk Sandhu, } \\
\text { Himanta Bansal, } \\
\text { Vijaypal Khanna [9] } \\
\end{array}$ & 2011, India & $\mathrm{F}$ & 47-years old & Extraction & $\begin{array}{l}\text { Extraction \& } \\
\text { Fabrication of a } \\
\text { complete denture }\end{array}$ & $\begin{array}{l}\text { Left erupted Maxillary second } \\
\text { molar with an impacted third } \\
\text { molar }\end{array}$ \\
\hline $\begin{array}{l}\text { Sagar Khanna, } \\
\text { Simarpreet Virk Sandhu, } \\
\text { Himanta Bansal, } \\
\text { Vijaypal Khanna [9] }\end{array}$ & 2011, India & F & 47-years old & Extraction & $\begin{array}{l}\text { Extraction \& } \\
\text { Fabrication of a } \\
\text { complete denture }\end{array}$ & $\begin{array}{l}\text { Left erupted Maxillary second } \\
\text { molar with an impacted third } \\
\text { molar }\end{array}$ \\
\hline $\begin{array}{l}\text { V Bellapu, } \\
\text { S Nagarakanti [4] }\end{array}$ & 2009, India & F & 35-years old & Extraction & Pain & $\begin{array}{l}\text { Right erupted Maxillary second } \\
\text { molar with an impacted third } \\
\text { molar }\end{array}$ \\
\hline Gernhofer KJ [10] & 2009, USA & M & 30-years old & Extraction & $\begin{array}{l}\text { Request for } \\
\text { extraction of } \\
\text { wisdom teeth }\end{array}$ & $\begin{array}{l}\text { Right erupted Maxillary second } \\
\text { molar with an impacted third } \\
\text { molar }\end{array}$ \\
\hline $\begin{array}{l}\text { Badjate SJ, Cariappa } \\
\text { KM [11] }\end{array}$ & 2008, India & M & 39-years old & Extraction & $\begin{array}{l}\text { Referred for } \\
\text { extraction of a } \\
\text { submerged and } \\
\text { decayed maxillary } \\
\text { left second molar }\end{array}$ & $\begin{array}{l}\text { Left submerged Maxillary } \\
\text { second molar with an impacted } \\
\text { third molar }\end{array}$ \\
\hline $\begin{array}{l}\text { Gunduz K, Sumer M, } \\
\text { Sumer AP, Gunhan O } \\
{[12]}\end{array}$ & 2006, Turkey & M & 21-years old & Extraction & Pain & $\begin{array}{l}\text { Right impacted Mandibular third } \\
\text { molar with an impacted } \\
\text { supernumerary fourth molar }\end{array}$ \\
\hline Romito L [13] & 2004, USA & M & 62-years old & Extraction & $\begin{array}{l}\text { Comprehensive } \\
\text { dental care }\end{array}$ & $\begin{array}{l}\text { Right erupted Maxillary second } \\
\text { molar with an impacted third } \\
\text { molar }\end{array}$ \\
\hline
\end{tabular}

